\title{
Kinetics in vitro of ruminal fermentation of cocoa husks subjected to alkali and heat treatment
}

\section{Cinética de fermentação ruminal in vitro da casca de cacau submetida a tratamento alcalino e térmico}

\author{
Flávio Moreira de Almeida ${ }^{1}$; José Augusto Gomes Azevêdo ${ }^{2 *}$; \\ Ícaro dos Santos $\mathrm{Cabral}^{3}$; Luiz Gustavo Ribeiro Pereira ${ }^{4}$; \\ Gherman Garcia Leal de Araújo ${ }^{5}$; Abdon Santos Nogueira ${ }^{6}$; Lígia Lins Souza \\ Brena Santos Oliveira ${ }^{8}$; Pablo Almeida Sampaio Vieira ${ }^{9}$
}

\begin{abstract}
The objective was to evaluate the parameters of kinetics of ruminal fermentation of cocoa husks $(\mathrm{CH})$ treated with alkali and thermal agents, using the semi-automated in vitro gas production technique. Cocoa husks samples were subjected to alkali and thermal methods (effect of time of exposure) treatment, as follows: control; alkaline treatment with calcium hydroxide $\left(\left(\mathrm{Ca}(\mathrm{OH})_{2}\right)\right.$ and calcium oxide $(\mathrm{CaO})$, both doses of $15.0 ; 30.0$ and $45.0 \mathrm{~g} \mathrm{~kg}^{-1}$ of CH; heat treatment in an autoclave at a pressure of $1.23 \mathrm{~kg} \mathrm{~cm}^{-2}(15$ psi) and a temperature of $123^{\circ} \mathrm{C}$ for 30,60 and 90 minutes. For statistical analysis, orthogonal contrasts and regression. The degradation rate and the final volume of gases of non-fiber carbohydrates decreased with the addition of $\mathrm{Ca}(\mathrm{OH})_{2}$ and $\mathrm{CaO}$, however, for fibrous carbohydrates effects were positive. For each percentage of $\mathrm{Ca}(\mathrm{OH})_{2}$ and $\mathrm{CaO}$ included, it is estimated an increase of 5.74 and $2.9 \%$ in the final volume of the fiber, respectively. When the heat treatment, a decrease in all parameters was estimated. For each minute of exposure to heat, there was a decrease of $0.4 \%$ in total final volume of gases. The alkali treatment can be an efficient alternative for improving the digestibility of fibrous fractions of $\mathrm{CH}$. Key words: Alternative feed, chemical treatment, residue, ruminants
\end{abstract}

\section{Resumo}

Objetivou-se avaliar os parâmetros da cinética de fermentação ruminal da casca de cacau (CC) tratada com agentes alcalinos e térmicos, utilizando a técnica in vitro semi-automática de produção de gases. Amostras da CC foram submetidas aos métodos de tratamento alcalino e térmico (efeito do tempo de exposição), assim distribuídos: controle; tratamento alcalino com hidróxido de cálcio $\left(\mathrm{Ca}(\mathrm{OH})_{2}\right)$ e óxido de cálcio $(\mathrm{CaO})$ ambos nas doses de 15,0; 30,0 e 45,0 $\mathrm{g} \mathrm{kg}^{-1}$ da CC; tratamento térmico em autoclave

${ }_{1}$ M.e em Ciência Animal, Dept ${ }^{0}$ de Ciências Agrárias e Ambientais, Universidade Estadual de Santa Cruz, UESC, Ilhéus, BA, Brasil. E-mail: flavi_vet@yahoo.com.br

2 Prof. Titular, Dept ${ }^{\circ}$ de Ciências Agrárias e Ambientais, UESC, Ilhéus, BA, Brasil. E-mail: augustog@uesc.br

3 M.e em Ciência Animal, Dept ${ }^{\circ}$ de Ciências Agrárias e Ambientais, UESC, Ilhéus, BA, Brasil. E-mail: i.s.cabral@hotmail.com

4 Pesquisador, Empresa Brasileira de Pesquisa Agropecuária, Embrapa Gado de Leite, Juiz de Fora, MG, Brasil. E-mail: luiz. gustavo@embrapa.br

5 Pesquisador, EMBRAPA Semi-Árido, Petrolina, PE, Brasil. E-mail: gherman.araujo@embrapa.br

6 Prof., Instituto Federal de Ciência e Tecnologia Baiano, Santa Inês, BA, Brasil. E-mail: abdon.nogueira@si.ifbaiano.edu.br

Discente de Doutorado, Universidade Estadual do Sudoeste da Bahia, UESB, Itapetinga, BA, Brasil. E-mail: ligia_lins@yahoo. com.br

8 Discente de Doutorado em Ciência Animal, UESC, Ilhéus, BA, Brasil. E-mail: brenabso@gmail.com

9 Discente de Doutorado, UESB, Itapetinga, BA, Brasil. E-mail: pablovieira1414@gmail.com

* Author for correspondence 
com pressão de $1,23 \mathrm{~kg} \mathrm{~cm}^{-2}$ (15 psi) e temperatura de $123^{\circ} \mathrm{C}$ durante 30,60 e 90 minutos. Para análise estatística, foram utilizados contrastes ortogonais e regressão. A taxa de degradação e o volume final dos gases dos carboidratos não fibrosos decresceram com a inclusão de $\mathrm{Ca}(\mathrm{OH})_{2} \mathrm{e} \mathrm{CaO}$, entretanto, para os carboidratos fibrosos os efeitos foram positivos. Para cada percentual de $\mathrm{Ca}(\mathrm{OH})_{2}$ e $\mathrm{CaO}$ incluídos, estima-se um acréscimo de 5,74 e 2,9\% no volume final dos carboidratos fibrosos respectivamente. Quanto ao tratamento térmico, houve decréscimo em todos os parâmetros estimados. Para cada minuto de exposição ao calor, houve diminuição de $0,4 \%$ no volume final total dos gases. O tratamento alcalino pode ser uma alternativa eficaz para a melhoria da digestibilidade das frações fibrosas da CC.

Palavras-chave: Alimentos alternativos, resíduo, ruminantes, tratamento químico

\section{Introduction}

Verticalization in agriculture has resulted in greater resource generation for the entire production chain. By processing commodities, the agricultural industries in Brazil increase their final product's value and thereby strengthen the country's position as a major food producer. However, a large amount of agro-industrial waste is generated in the process that must be dealt with in accordance with environmental laws.

Using byproducts left from processing cocoa almonds (cocoa husks) in feed for ruminants has already been a matter of study for some time (ALY, 1981). This byproduct is composed of the integument that surrounds the cocoa almond's core and its chemical composition depends a lot on the different types industrial processing machinery used, which cause the amount of crude protein (CP) to vary from 135.0 (MARCONDES et al., 2009) to $169.0 \mathrm{~g} \mathrm{~kg}^{-1}$ of dry matter (DM) (OLIVEIRA et al., 2010), this is due to the greater or lesser presence of NIBS (fragmented cotyledons from the cocoa seed), which is the raw material used during chocolate manufacturing.

Cocoa Husks $(\mathrm{CH})$ are considered byproducts that have a relatively low nutritional value (TDN of $588.3 \mathrm{~g} \mathrm{~kg}^{-1} \mathrm{DM}$ ) and high cell-wall content, which is associated with a high lignin content (185.4 $\mathrm{g} \mathrm{kg}^{-1} \mathrm{DM}$ ) (AZEVÊDO et al., 2011). Ruminant diets with $\mathrm{CH}$ can have a negative impact on intake, this is because a portion of the ingested fiber that is resistant to fermentation by ruminal microorganisms accumulates in the rumen compared with the potentially digestible fraction (ALLEN;
MERTENS, 1987) and consequently, has a direct effect in terms of reducing animal performance (ALY, 1981; AREGHEORE, 2002; CARVALHO et al., 2004; MARCONDES et al., 2009; AZEVÊDO et al., 2011). Thus, alternatives designed to increase the potentially digestible fraction of fiber or its digestion rate can have positive impacts on the animals' intake and performance. In this sense, alkalizing agents can be used to improve the digestibility of agro-industrial byproducts (PINA et al., 2011).

During digestibility studies in cattle, results obtained in vivo have always been more realistic, however they are limited due to the fact that they require a representative number of animals, in addition to needing large quantities of feeds that may be used during the adjustment and experimental periods.

In vitro methodologies for evaluating feeding have been used to determine the nutritional value of forage, with a high correlation between consumption and in vivo digestibility being registered (ØRSKOV, 2002). This study aimed to evaluate the effects of alkaline and thermal treatments in cocoa husks on the kinetic parameters of in vitro ruminal fermentation.

\section{Material and Methods}

\section{Location}

The experiment was conducted on the premises of the Animal Nutrition Laboratory under the administration of the Department of Agricultural and Environmental Sciences at the State University of Santa Cruz located in Ilhéus, Southern Bahia. The 
cocoa husks $(\mathrm{CH})$ were obtained from a city known as Arataca - Bahia and consist of the integument that surrounds the almond core.

In order to evaluate how effective the treatments were, 50 samples, each with 250 grams of ground $\mathrm{CH}$, were placed into a $1 \mathrm{~mm}$ sieve and distributed in a completely randomized design, with five repetitions, and were subjected to 10 treatments in accordance with the alkaline and thermal treatment methods as follows: untreated control; alkaline treatment with calcium hydroxide $\mathrm{Ca}(\mathrm{OH})_{2}$ and calcium oxide $(\mathrm{CaO})$, diluted in water $(1: 10)$, in doses of 15.0, 30.0 and $45.0 \mathrm{~g} \mathrm{~kg}^{-1}$ of $\mathrm{CH}$, base of the natural matter; heat treatment in an autoclave with $1.23 \mathrm{~kg} \mathrm{~cm}^{-1}$ pressure (15 psi) and a temperature of $123^{\circ} \mathrm{C}$ for 30,60 and 90 minutes. After being exposed to hydrolysis for a 24-hour period, the material was taken to a forced ventilation oven set at $55^{\circ} \mathrm{C}$ for 24 hours.

\section{Bromatological analyses}

All samples were analyzed in accordance with procedures adopted by Detmann et al. (2012) for contents of DM, CP, organic matter (OM), ether extract (EE) and acid detergent fiber (ADF). During the neutral detergent fiber (NDF) analyses, the samples were corrected for ash and nitrogen. Nonfibrous carbohydrate (NFC) content, expressed as a \% in the DM, was calculated in accordance with Hall (2000), namely: 100- (\%NDF +\%CP +\%EE $+\% \mathrm{MM})$. These values can be seen in Table 1 .

Table 1. Bromatological chemical composition of cocoa husks exposed to alkaline and thermal treatments.

\begin{tabular}{|c|c|c|c|c|c|c|c|c|c|c|}
\hline \multirow{3}{*}{ Item } & \multirow{3}{*}{ Control } & \multicolumn{6}{|c|}{ Alkaline treatment } & \multirow{2}{*}{\multicolumn{3}{|c|}{$\begin{array}{c}\text { Heat treatment } \\
\text { Time }(\mathrm{min})\end{array}$}} \\
\hline & & \multicolumn{3}{|c|}{$\mathrm{Ca}(\mathrm{OH})_{2}$} & \multicolumn{3}{|c|}{$\mathrm{CaO}$} & & & \\
\hline & & 15.0 & 30.0 & 45.0 & 15.0 & 30.0 & 45.0 & 30 & 60 & 90 \\
\hline $\mathrm{DM}^{1}$ & 964.0 & 945.0 & 963.0 & 940.0 & 930.0 & 937.0 & 924.0 & 942.0 & 948.0 & 948.0 \\
\hline $\mathrm{OM}^{2}$ & 929.0 & 905.0 & 904.0 & 891.0 & 913.0 & 898.0 & 893.0 & 922.0 & 928.0 & 932.0 \\
\hline $\mathrm{CP}^{2}$ & 152.0 & 146.0 & 149.0 & 148.0 & 155.0 & 153.0 & 154.0 & 155.0 & 153.0 & 154.0 \\
\hline $\mathrm{EE}^{2}$ & 92.0 & 98.0 & 92.0 & 105.0 & 117.0 & 107.0 & 122.0 & 154.0 & 132.0 & 124.0 \\
\hline $\mathrm{NDFap}^{2}$ & 517.0 & 559.0 & 568.0 & 560.0 & 538.0 & 541.0 & 543.0 & 514.0 & 521.0 & 519.0 \\
\hline $\mathrm{ADFap}^{2}$ & 489.0 & 500.0 & 457.0 & 462.0 & 451.0 & 495.0 & 491.0 & 485.0 & 508.0 & 479.0 \\
\hline $\mathrm{NFC}^{2}$ & 167.0 & 102.0 & 94.0 & 78.0 & 102.0 & 97.0 & 73.0 & 99.0 & 121.0 & 136.0 \\
\hline $\mathrm{NDICP}^{3}$ & 344.0 & 371.0 & 362.0 & 370.0 & 361.0 & 367.0 & 353.0 & 358.0 & 365.0 & 383.0 \\
\hline $\mathrm{ADICP}^{3}$ & 274.0 & 282.0 & 245.0 & 247.0 & 281.0 & 267.0 & 273.0 & 358.0 & 255.0 & 254.0 \\
\hline
\end{tabular}

DM, dry matter; OM, organic matter; CP, crude protein; EE, ether extract; NDFap, ash and protein-free neutral detergent fiber; ADFap, ash and protein-free acid detergent fiber; NFC, non-fibrous carbohydrates; NDICP, neutral detergent insoluble crude protein; ADICP, acid detergent insoluble crude protein.

${ }^{1} \mathrm{~g} / \mathrm{kg}$ natural matter

${ }^{2} \mathrm{~g} / \mathrm{kg}$ dry matter

${ }^{3} \mathrm{~g} / \mathrm{kg}$ crude protein.

\section{Kinetics of in vitro ruminal fermentation}

In vitro incubations by the semi-automatic gas production technique were performed in accordance with that as described by Santos et al. (2010). Were weighed $300 \mathrm{mg}$ samples of each treatment, in four repetitions, and deposited in $50 \mathrm{~mL}$ glass flasks.

The ruminal inoculant was obtained from a rumen fistulated bovine male, which after filtering was put in a thermos that had been pre-heated to $39^{\circ} \mathrm{C}$ and immediately taken to the laboratory for incubation in the flasks.

The pressure from the accumulated gases at the top of the flasks was measured using a "Press DATA 800 " pressure transducer attached to a $6 \mathrm{~mm}$ syringe, at $1,2,3,4,6,12,14,8,10,17,20,24,28,36,48$, $60,72,84,96,108$ and 120 hours after incubation. 
The regression equation used to convert pressure $(\mathrm{P})$ to volume $(\mathrm{mL})=0.04755+1.9754 \mathrm{P}$ $+0.01407 \mathrm{P}^{2},\left(\mathrm{R}^{2}=0.99\right)$, was standardized in accordance with Santos et al. (2010) following the methodology proposed by Maurício et al. (2003). A bicompartimental model was used which was fitted to cumulative gas production curves (SCHOFIELD et al., 1994) with the following equation.

$\mathrm{V}=\mathrm{FVNFC} /\left(1+\exp \left(2-4 * \mathrm{kdNFC}^{*}(\mathrm{~T}-\right.\right.$ $\mathrm{L})))+\mathrm{VFFC} /\left(1+\exp \left(2-4 * \mathrm{kdFC}^{*}(\mathrm{~T}-\mathrm{L})\right)\right)$, where: FVNFC is equivalent to the maximum volume of gases from the NFC fraction; kdNFC is the degradation rate $\left(\mathrm{h}^{-1}\right)$ of this fraction; VFFC is the maximum volume of gas from the fibrous carbohydrates fraction (FC); $\mathrm{kdFC}$ is the degradation rate $\left(\mathrm{h}^{-1}\right)$ of the $\mathrm{FC}$; $\mathrm{T}$ and $\mathrm{L}$ are the incubation (hours) and latency (hours) times, respectively.

\section{Statistical analyses}

The data obtained on the gas production parameters from the NFC and FC was fitted by nonlinear regression using the Gauss-Newton method, which is implemented in the Statistical Analysis System software. Analyses of variance were performed and, when significant, were compared to the means between treatments using orthogonal contrasts (Table 2).

Table 2. Distribution of coefficients for the orthogonal contrasts.

\begin{tabular}{|c|c|c|c|c|c|c|c|c|c|c|}
\hline \multirow{2}{*}{ Item } & \multirow{2}{*}{ Control } & \multicolumn{3}{|c|}{$\mathrm{Ca}(\mathrm{OH})$} & \multicolumn{3}{|c|}{$\mathrm{CaO}$} & \multicolumn{3}{|c|}{ Heat (min) } \\
\hline & & 15 & 30 & 45 & 15 & 30 & 45 & 30 & 60 & 90 \\
\hline 1 & +3 & -1 & -1 & -1 & 0 & 0 & 0 & 0 & 0 & 0 \\
\hline 2 & +3 & 0 & 0 & 0 & -1 & -1 & -1 & 0 & 0 & 0 \\
\hline 3 & +3 & 0 & 0 & 0 & 0 & 0 & 0 & -1 & -1 & -1 \\
\hline 4 & 0 & 1 & 1 & 1 & -1 & -1 & -1 & 0 & 0 & 0 \\
\hline 5 & 0 & 1 & 1 & 1 & 0 & 0 & 0 & -1 & -1 & -1 \\
\hline 6 & 0 & 0 & 0 & 0 & 1 & 1 & 1 & -1 & -1 & -1 \\
\hline
\end{tabular}

Whenever significance was present, regression analysis was performed on the treatment levels or time. The models were selected on the basis of the coefficients of determination and the significance of the regression coefficients.

\section{Results and Discussions}

\section{Degradation curves}

In the curves from the kinetics of in vitro ruminal fermentation, a higher total final volume (TFV) was observed for $\mathrm{CH}$ treated with $15.0 \mathrm{~g}$ of $\mathrm{CaO}$. Considering the linear relationship between the disappearance of total carbohydrates (TC) and the TFV (PELL et al., 1994), it can be inferred that this treatment was the one that made a greater disappearance of TC possible compared with the others (Figures 1, 2 and 3).

It is possible that there might have been greater ester type ruptures in the links between the lignin, the cellulose structural carbohydrates and the hemicellulose, which in turn provides these components in greater quantity when compared to other treatments. Macedo et al. (2011) suggested that adding $\mathrm{CaO}$ improves the degradability of the dry matter and the fibrous fraction, suggesting that its use is advantageous. Less TVF was observed in the thermally treated samples, indicating a lower utilization of carbohydrates (Figure 3). 
Figure 1. Gas production from in vitro ruminal fermentation depending on the incubation times of cocoa husks treated with $0 ; 1.5 ; 3.0$ and $4.5 \%$ of $\mathrm{Ca}(\mathrm{OH})_{2}$.

in natura

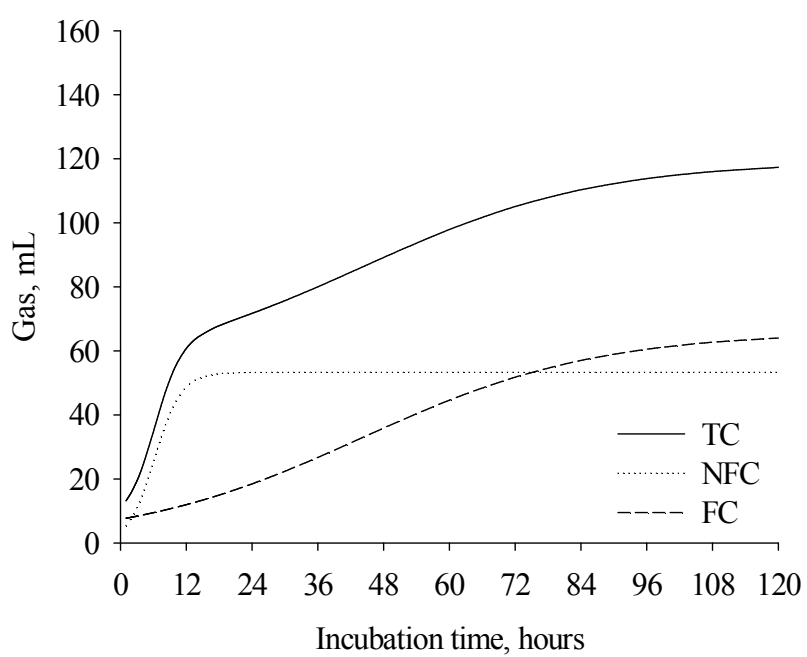

$3.0 \% \mathrm{Ca}(\mathrm{OH})_{2}$



$1.5 \% \mathrm{Ca}(\mathrm{OH})_{2}$



$4.5 \% \mathrm{Ca}(\mathrm{OH})_{2}$




Figure 2. Gas production from in vitro ruminal fermentation depending on the incubation times of cocoa husks treated with $0 ; 1.5 ; 3.0$ and $4.5 \%$ of $\mathrm{CaO}$.

in natura

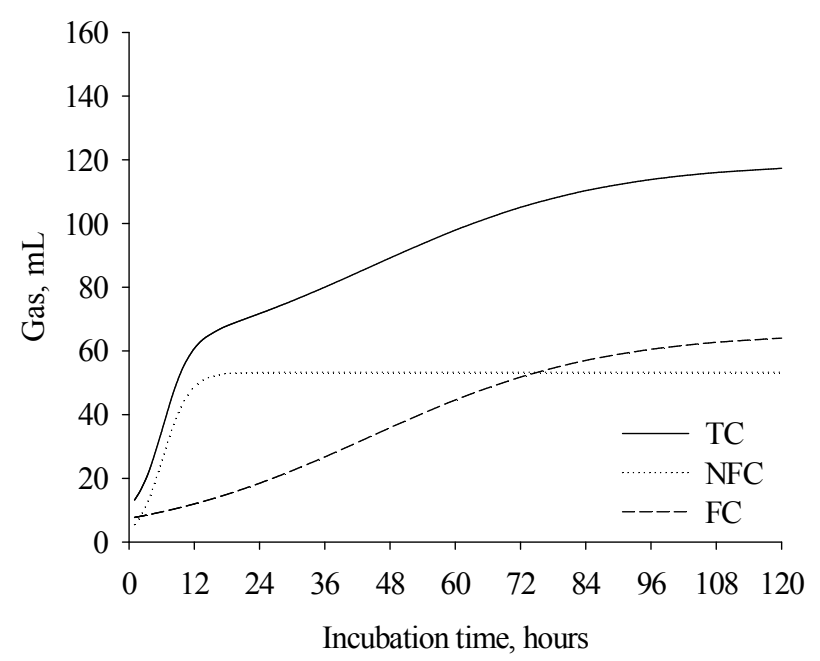

$3.0 \% \mathrm{CaO}$

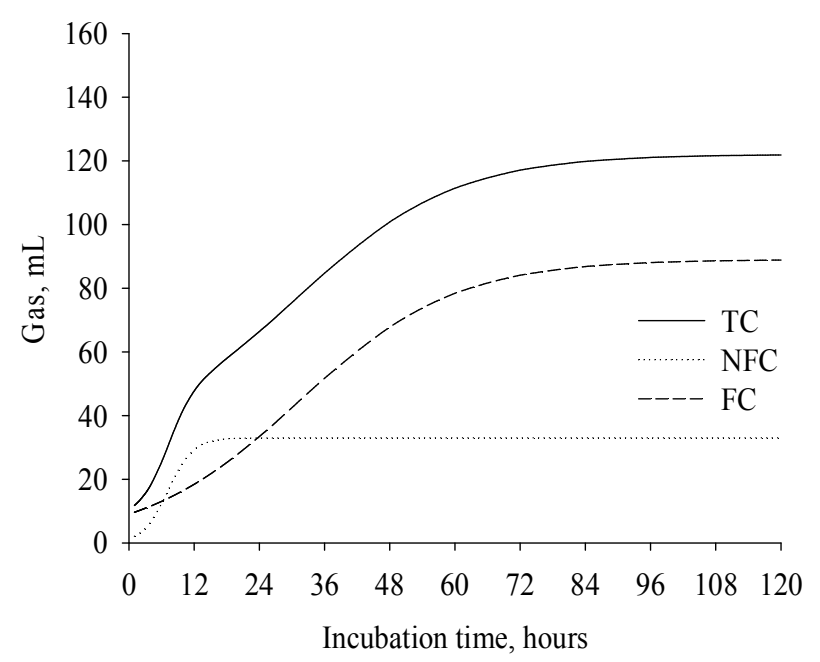

$1.5 \% \mathrm{CaO}$



$4.5 \% \mathrm{CaO}$

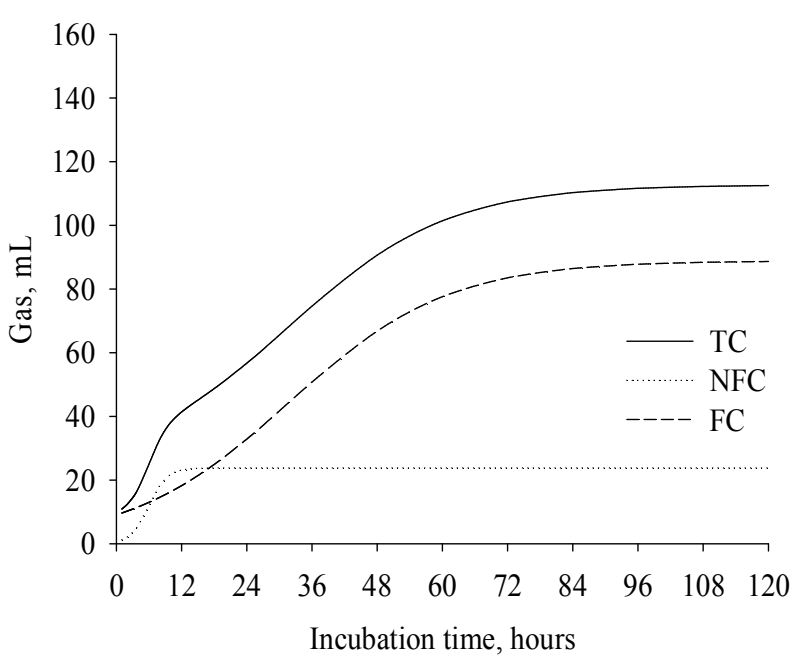


Figure 3. Gas production from in vitro ruminal fermentation depending on the incubation times of cocoa husks exposed to $1.23 \mathrm{~kg} / \mathrm{cm}$ pressure $(15 \mathrm{psi})$ and a $123^{\circ} \mathrm{C}$ temperature for $0,30,60$ and 90 minutes.

in natura

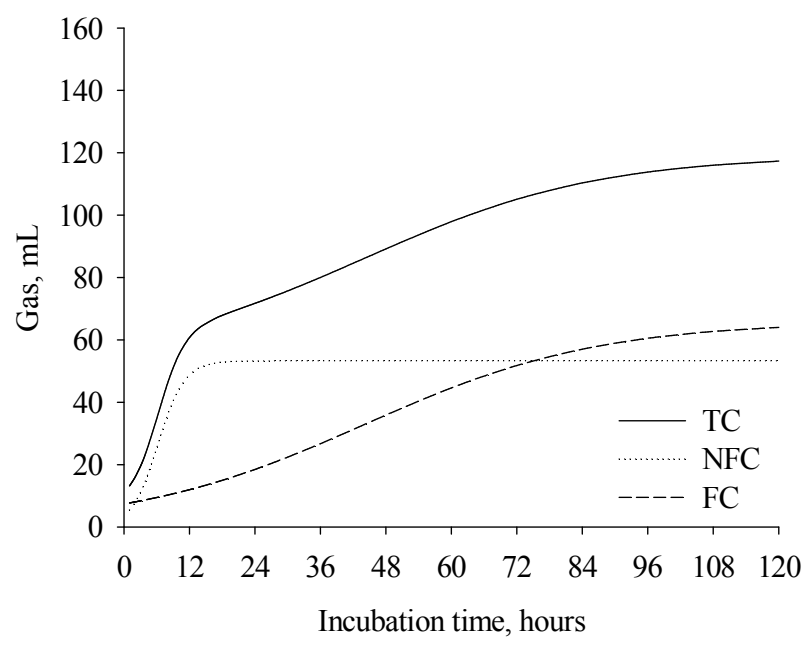

60 minutes

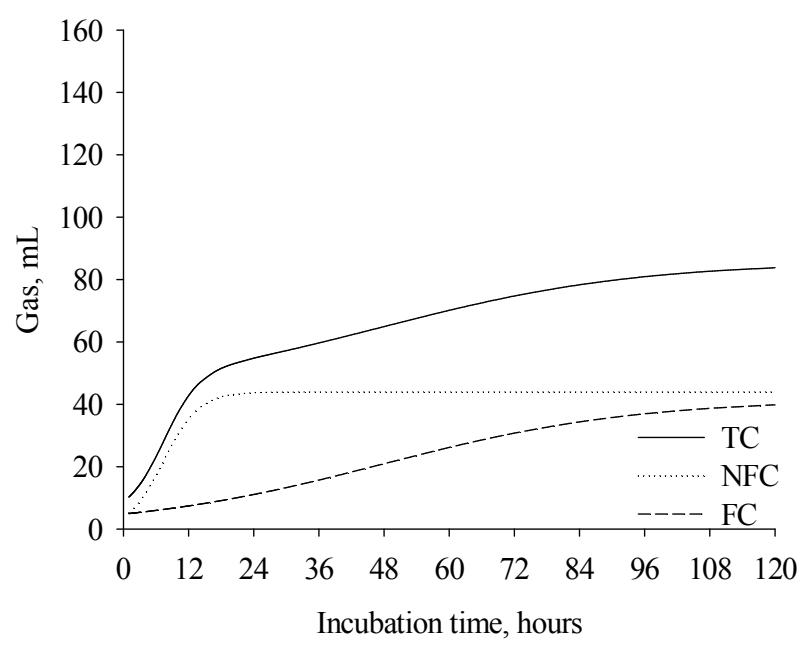

Result from the contrasts

Mean estimates of the kinetic parameters of in vitro ruminal fermentation of the non-fibrous carbohydrates (NFC) and fibrous carbohydrates (FC) (Table 3) indicate differences $(\mathrm{P}<0.05)$

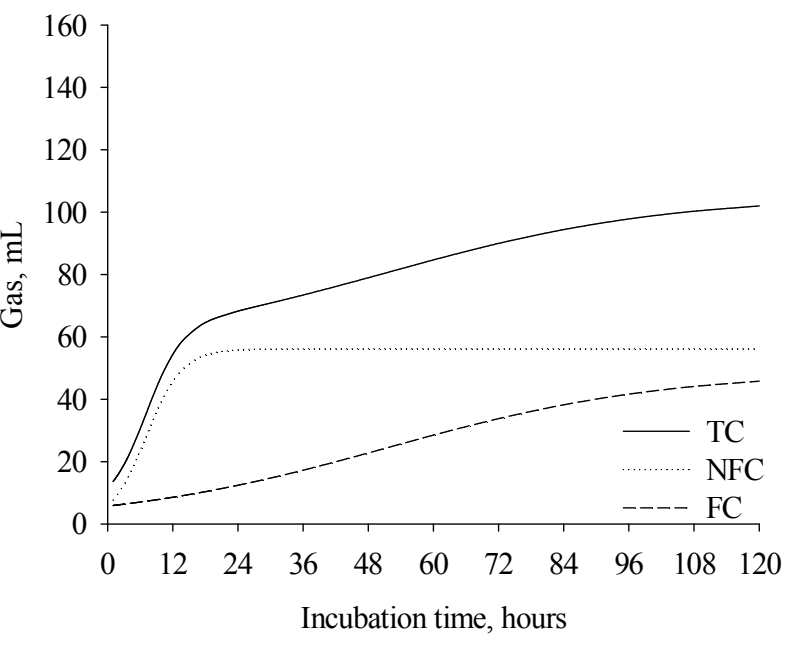

90 minutes

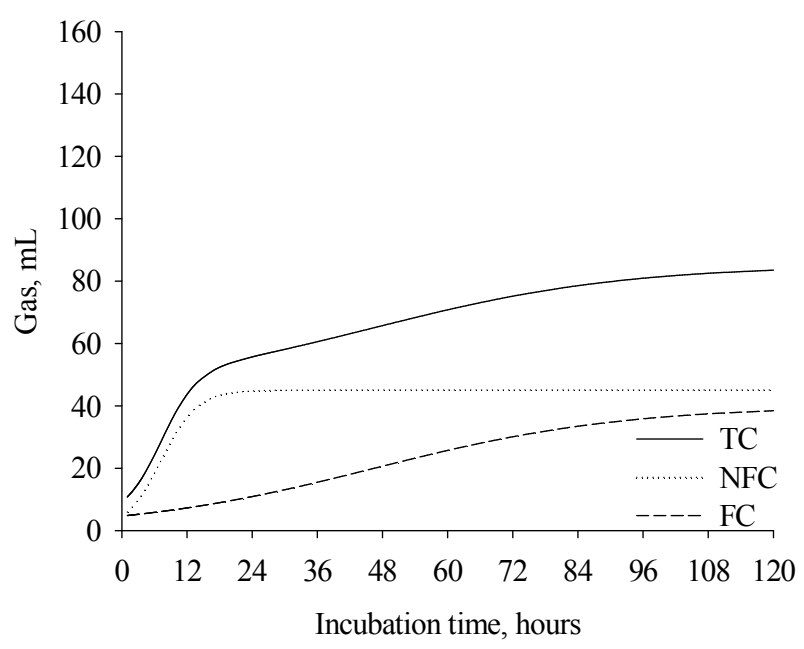

between the samples analyzed for the contrasts 1,2 , 4, 5 and 6 (Table 4). However, in contrast 3 no effect was observed $(\mathrm{P}>0.05)$ for the latency time $(L)$ parameter, and in contrast 5 no effect was observed $(\mathrm{P}>0.05)$ for the $\mathrm{FC}$ degradation rate $(\mathrm{kdFC})$ or TFV parameters. 
Table 3. Kinetic parameters of in vitro ruminal fermentation from the non-fibrous and fibrous carbohydrates of cocoa husks treated with alkaline agents, and of those exposed to pressure and temperature.

\begin{tabular}{|c|c|c|c|c|c|c|}
\hline \multirow{2}{*}{ Item } & \multicolumn{6}{|c|}{ Parameters } \\
\hline & $\mathrm{fvNFC}^{1}$ & $\mathrm{kdNFC}^{2}$ & $\mathrm{~L}^{3}$ & $\mathrm{fvFC}^{1}$ & $\mathrm{kdFC}^{2}$ & $\mathrm{fvT}^{1}$ \\
\hline \multirow[t]{2}{*}{ Control } & 53.300 & 0.104 & 1.424 & 65.872 & 0.012 & 119.171 \\
\hline & \multicolumn{6}{|c|}{$\mathrm{Ca}(\mathrm{OH})_{2}$} \\
\hline $15.0 \mathrm{~g}$ & 55.226 & 0.085 & 0.817 & 73.512 & 0.016 & 128.738 \\
\hline $30.0 \mathrm{~g}$ & 36.661 & 0.093 & 1.644 & 87.758 & 0.017 & 124.419 \\
\hline $45.0 \mathrm{~g}$ & 32.224 & 0.101 & 1.948 & 89.862 & 0.017 & 122.085 \\
\hline \multirow[t]{2}{*}{ Mean } & 41.370 & 0.093 & 1.470 & 83.711 & 0.016 & 125.081 \\
\hline & \multicolumn{6}{|c|}{$\mathrm{CaO}$} \\
\hline $15.0 \mathrm{~g}$ & 48.420 & 0.085 & 1.228 & 94.507 & 0.016 & 142.928 \\
\hline $30.0 \mathrm{~g}$ & 33.017 & 0.108 & 2.579 & 89.050 & 0.017 & 122.067 \\
\hline $45.0 \mathrm{~g}$ & 23.843 & 0.146 & 2.555 & 88.880 & 0.017 & 112.723 \\
\hline \multirow[t]{2}{*}{ Mean } & 35.093 & 0.113 & 2.121 & 90.813 & 0.017 & 125.906 \\
\hline & \multicolumn{6}{|c|}{ Heat treatment } \\
\hline $30 \mathrm{~min}$ & 56.185 & 0.075 & 0.487 & 48.927 & 0.009 & 105.111 \\
\hline $60 \mathrm{~min}$ & 43.970 & 0.077 & 0.981 & 41.634 & 0.010 & 85.605 \\
\hline $90 \mathrm{~min}$ & 45.073 & 0.075 & 0.625 & 40.007 & 0.010 & 85.080 \\
\hline Mean & 48.409 & 0.076 & 0.698 & 43.523 & 0.010 & 91.933 \\
\hline
\end{tabular}

fvNCF, final volume of the non-fiber carbohydrates; kdCNF, degradation rate of the non-fiber carbohydrates; L, lag time; fvFC, final volume of the fiber carbohydrates; kdNFC, degradation rate of the fiber carbohydrates; fvT, final volume total.

${ }^{1} \mathrm{ml} \quad{ }^{2}\left(\mathrm{~h}^{-1}\right) \quad{ }^{3}$ hours.

Table 4. Error type I probability $\left(\mathrm{P}\right.$ Value $\left.{ }^{-1}\right)$ associated with the $\mathrm{t}$ test for the orthogonal contrasts.

\begin{tabular}{lcccccc}
\hline \multirow{2}{*}{ Item } & \multicolumn{7}{c}{ Contrasts } \\
\cline { 2 - 6 } & 1 & 2 & 3 & 4 & 5 & 6 \\
\hline fvNFC & $<0.0001$ & $<0.0001$ & $<0.0001$ & $<0.0001$ & $<0.0001$ & $<0.0001$ \\
kdNFC & 0.0261 & $<0.0001$ & 0.0141 & $<0.0001$ & $<0.0001$ & $<0.0001$ \\
L & $<0.0001$ & $<0.0001$ & 0.7151 & $<0.0001$ & $<0.0001$ & $<0.0001$ \\
fvFC & $<0.0001$ & $<0.0001$ & $<0.0001$ & $<0.0001$ & $<0.0001$ & $<0.0001$ \\
kdFC & $<0.0001$ & $<0.0001$ & $<0.0001$ & $<0.0001$ & 0.0531 & $<0.0001$ \\
fvT & $<0.0001$ & $<0.0001$ & $<0.0001$ & $<0.0001$ & 0.0714 & $<0.0001$ \\
\hline
\end{tabular}

fvNCF, final volume of the non-fiber carbohydrates; kdCNF, degradation rate of the non-fiber carbohydrates; L, lag time; fvFC, final volume of the fiber carbohydrates; kdNFC, degradation rate of the fiber carbohydrates; fvT, final volume total.

\section{Control contrast: $\mathrm{Ca}(\mathrm{OH})_{2}$}

There was a reduction in the NFC degradation rate (kdNFC) and in the NFC final volume (FVNFC), with the inclusion of $\mathrm{Ca}(\mathrm{OH})_{2}$ for the alkaline treatment of cocoa husks. This result can be attributed to lower gas production in the early times, with this being the most representative period for the bicompartimental model, with regards to the NFC fermentation parameters.
According to Pell et al. (1997), the contribution from the high quality voluminous soluble fraction is responsible for the volume of gases produced during the first 15 fermentation hours. During this period, microbial mass production occurs practically independent of the fibrous carbohydrates. However, cocoa husks have high lignin content and low soluble carbohydrate content, therefore the soluble fraction may not have been representative when compared to the high quality forage. 
For the levels of $\mathrm{Ca}(\mathrm{OH})_{2}$ inclusion, there was an observed decrease of $5.4 \%$ in the FVNFC for each unit percentage when $\mathrm{Ca}(\mathrm{OH})_{2}$ was added to the $\mathrm{CH}$ (Table 5). The kdNFC and L showed quadratic behavior with a minimum point estimated at 2.24 and $1.46 \%$ of $\mathrm{Ca}(\mathrm{OH})_{2}$ in cocoa husks, respectively. It is possible that adding an alkaline agent such as
$\mathrm{Ca}(\mathrm{OH})_{2}$ in the $\mathrm{CH}$ raised the $\mathrm{pH}$ of the in vitro environment and did not provide suitable conditions for developing a microbial population that was able to degrade the NFC, which resulted in decreased FVNFC and the minimum point kdNFC behavior, as was measured when $\mathrm{Ca}(\mathrm{OH})_{2}$ was added to $\mathrm{CH}$.

Table 5. Solution of the fixed effects regression equations for the kinetic parameters of in vitro ruminal fermentation, and their respective coefficients of determination for $\mathrm{Ca}(\mathrm{OH})_{2}$ inclusion levels in cocoa husks.

\begin{tabular}{lcccccc}
\hline Parameters & fvNFC & kdNFC & L & fvFC & kdFC & fvT \\
\hline Intercept & 56.62 & 0.102 & 13.26 & 66.31 & 0.0119 & 119.96 \\
$\mathrm{SE}$ & 13.05 & 0.03 & 0.11 & 0.86 & 0.02 & 0.65 \\
$\mathrm{P}^{-1}$ & $<0.0001$ & $<0.0001$ & $<0.0001$ & $<0.0001$ & $<0.0001$ & $<0.0001$ \\
Level of $\mathrm{Ca}(\mathrm{OH})_{2}$ & -54.53 & -0.01 & -0.29 & 57.47 & 0.003 & 62.45 \\
$\mathrm{EP}$ & 0.465 & 0.003 & 0.121 & 0.3097 & 0.003 & 0.701 \\
$\mathrm{P}^{-1}$ & $<0.0001$ & 0.001 & 0.020 & $<0.0001$ & $<0.0001$ & $<0.0001$ \\
Level of $\mathrm{Ca}(\mathrm{OH})_{2}$ & & 0.003 & 0.101 & & -0.004 & -13.22 \\
$\mathrm{SE}$ & & 0.08 & 0.25 & & 0.01 & 0.14 \\
$\mathrm{P}^{-1}$ & & 0.009 & 0.004 & & $<0.0001$ & $<0.0001$ \\
$\mathrm{r}^{2}$ & 0.83 & 0.85 & 0.72 & 0.94 & 0.96 & 0.74 \\
\hline
\end{tabular}

fvNCF, final volume of the non-fiber carbohydrates; kdCNF, degradation rate of the non-fiber carbohydrates; L, lag time; fvFC, final volume of the fiber carbohydrates; kdNFC, degradation rate of the fiber carbohydrates; fvT, final volume total; SE, standard error.

Whereas for the $\mathrm{FC}$, it was observed that for each increase in the unit percentage of $\mathrm{Ca}(\mathrm{OH})_{2}$, the VFC increased by $5.75 \%$. The $\mathrm{kdFC}$ and TFV had quadratic behavior with a maximum point estimated at 3.42 and $2.36 \% \mathrm{Ca}(\mathrm{OH})_{2}$, respectively.

The increase in the $\mathrm{Ca}(\mathrm{OH})_{2}$ concentration may have resulted in the $\mathrm{pH}$ being maintained near neutral for a longer period of time compared to the control treatment. This phenomenon may have been favorable for fibrocystic microorganisms, which, according to Dijkstra et al. (2012), the majority of cellulase are highly sensitive to variations of ruminal $\mathrm{pH}$, and that none of the ruminal cellulolytic bacteria grow at $\mathrm{pH}$ values that are significantly below 6.0.

It is possible to infer that in spite of this reduction in kdNFC and FVNFC, including this alkali provided a greater extent and speed in FC degradation which resulted in a greater extent in TC degradation and nutrient availability to the population of in vitro microorganisms.

\section{Control contrast: $\mathrm{CaO}$}

There was an increase $(\mathrm{P}<0.05)$ in $\mathrm{kdFC}$ and in VFFC, which was detrimental to kdNFC and in the FVNFC. The results found for the $\mathrm{CH}$ that were treated with $\mathrm{CaO}$ pointed out the best use of the $\mathrm{CH}$ fibrous fraction.

For each percentage unit of $\mathrm{CaO}$ in the $\mathrm{CH}$, there was an estimated decrease of $6.9 \%$ in the FVNFC and an increase of $0.3 \%$ in the L (Table 6). The kdNFC presented quadratic behavior with a minimum point estimated at $1.45 \%$ of $\mathrm{CaO}$ in the cocoa husk. For the $\mathrm{FC}$, the $\mathrm{kdFC}$ and the $\mathrm{vfFC}$ were observed to have quadratic behavior with a maximum point estimated at 2.91 and $3.37 \%$ of $\mathrm{CaO}$, respectively. The TFV had quadratic behavior with a maximum point estimated at $1.88 \%$ of $\mathrm{CaO}$ in the $\mathrm{CH}$. 
Table 6. Solution of the fixed effects regression equations for the kinetic parameters of in vitro ruminal fermentation, and their respective coefficients of determination for $\mathrm{CaO}$ inclusion levels in cocoa husks.

\begin{tabular}{lcccccc}
\hline Parameters & fvNFC & kdNFC & $\mathrm{L}$ & fvFC & kdFC & fvT \\
\hline Intercept & 55.21 & 0.10 & 1.23 & 67.84 & 0.01 & 121.97 \\
$\mathrm{SE}$ & 0.80 & 0.04 & 0.11 & 1.64 & 0.02 & 2.17 \\
$\mathrm{P}^{-1}$ & $<0.0001$ & $<0.0001$ & $<0.0001$ & $<0.0001$ & $<0.0001$ & $<0.0001$ \\
Level of $\mathrm{CaO}$ & -6.91 & -0.01 & 0.31 & 18.64 & 0.03 & 13.87 \\
$\mathrm{EP}$ & 0.01 & 0.04 & 0.04 & 1.75 & 0.01 & 2.33 \\
$\mathrm{P}^{-1}$ & & 0.0003 & $<0.0001$ & $<0.0001$ & $<0.0001$ & $<0.0001$ \\
Level of $\mathrm{CaO}$ & & 0.01 & & -3.20 & -0.01 & -3.67 \\
$\mathrm{SE}$ & & 0.01 & & 0.37 & 0.01 & 0.49 \\
$\mathrm{P}^{-1}$ & & $<0.0001$ & & $<0.0001$ & $<0.0001$ & $<0.0001$ \\
$\mathrm{r}^{2}$ & 0.97 & 0.98 & 0.72 & 0.99 & 0.99 & 0.69 \\
\hline
\end{tabular}

fvNCF, final volume of the non-fiber carbohydrates; kdCNF, degradation rate of the non-fiber carbohydrates; L, lag time; fvFC, final volume of the fiber carbohydrates; kdNFC, degradation rate of the fiber carbohydrates; fvT, final volume total; SE, standard error.

There were differences between the samples for the latency period, at which time no degradation of the substrate was verified. The samples that were subjected to alkaline treatment with $\mathrm{CaO}$ at levels of 30.0 and $45.0 \mathrm{~g} \mathrm{~kg}^{-1}$ were those that provided the greatest estimates for latency period, namely 2.57 and 2.55 hours, respectively, compared with the other samples. It is possible that the highest levels of $\mathrm{CaO}$ kept the $\mathrm{pH}$ high inside the flasks, thus not providing an ideal environment for microorganism activity in the early incubation days which involve substrate moisture, microbial colonization and adhesion, and may not have had full availability of rapidly fermentable components thereby resulting in slow gas production.

\section{Control contrast: thermal}

The $\mathrm{CH}$ submitted to pressure and temperature at the 90 minute time showed the worst results for all the evaluated parameters, with the exception of the Latency period. These results may be related to lesser availability of substrate capable of microbial fermentation that result from the negative effects caused by the Maillard reaction, since, in addition to the thermal exposure that occurred in the industry during cocoa processing, these samples were exposed for longer periods to temperature and heat in the autoclave.

The Maillard reaction occurs among reducing sugars and proteins and leads to Brown pigments being formed, which results from the reaction between the glucose and glycine. The reaction between the amino group and the carbonyl or ketone groups from the reducing carbohydrates occurs even at relatively low temperatures, this is due to the high energy from this type of reaction's activation (SHIBAO; BASTOS, 2011).

Despite there being good protein content (approx $150.0 \mathrm{~g} \mathrm{~kg}^{-1}$ of DM), the cocoa husk has low protein utilization, which is a result of high ADIN levels (PIRES et al., 2009). This protein fraction corresponds to proteins associated with lignin, tannin-protein complexes and products derived from the Maillard reaction.

For heat exposure levels at the time slots, there was an observed decrease of $0.12 \%$ in the FVNFC and an increase of $0.63 \%$ in $\mathrm{L}$ during each minute of treatment exposure for the cocoa husks (Table 7). The kdNFC presented quadratic behavior with a minimum point estimated at 64.06 minutes. 
Table 7. Solution of the fixed effects regression equations for the kinetic parameters of in vitro ruminal fermentation, and their respective coefficients of determination for time exposed to temperature and pressure for cocoa husks.

\begin{tabular}{|c|c|c|c|c|c|}
\hline Parameters & fvNFC & kdNFC & $\mathrm{L}$ & fvFC & $\mathrm{kdFC}$ \\
\hline Intercept & 55.16 & 0.10 & 65.67 & 0.01 & 117.00 \\
\hline SE & 10.17 & 0.01 & 0.65 & 0.01 & 13.68 \\
\hline $\mathrm{P}^{-1}$ & $<0.0001$ & $<0.0001$ & $<0.0001$ & $<0.0001$ & $<0.0001$ \\
\hline Time & -0.12 & -0.01 & -0.66 & -0.01 & -0.40 \\
\hline SE & 0.02 & 0.01 & 0.03 & 0.01 & 0.02 \\
\hline $\mathrm{P}^{-1}$ & $<0.0001$ & $<0.0001$ & $<0.0001$ & 0.0016 & $<0.0001$ \\
\hline Time $^{2}$ & & 0.01 & 0.01 & 0.01 & \\
\hline SE & & 0.01 & 0.01 & 0.01 & \\
\hline $\mathrm{P}^{-1}$ & & $<0.0001$ & $<0.0001$ & 0.0027 & \\
\hline $\mathrm{r}^{2} / \mathrm{R}^{2}$ & 0.62 & 0.90 & 0.99 & 0.64 & 0.91 \\
\hline
\end{tabular}

fvNCF, final volume of the non-fiber carbohydrates; kdCNF, degradation rate of the non-fiber carbohydrates; L, lag time; fvFC, final volume of the fiber carbohydrates; kdNFC, degradation rate of the fiber carbohydrates; fvT, final volume total; SE, standard error.

The kdFC and the VFFC had quadratic behavior with a minimum point estimated at 49.7 and 78.3 minutes of exposure to heat, respectively (Table 7). At every minute of exposure to heat, there was a $0.4 \%$ decrease in the TFV.

\section{$\mathrm{Ca}(\mathrm{OH})_{2}$ contrast: $\mathrm{CaO}$}

The FVNFC was higher $(\mathrm{P}<0.05)$ for $\mathrm{CH}$ treated with $\mathrm{Ca}(\mathrm{OH})_{2}$ when compared with those treated with $\mathrm{CaO}$. Whereas the $\mathrm{kdNFC}$ and $\mathrm{L}$ showed higher values $(\mathrm{P}<0.05)$ for the $\mathrm{CH}$ treated with $\mathrm{CaO}$. Despite the TFV that were estimated from the samples treated with the two sources being very close, there was no difference $(\mathrm{P}<0.05)$ between the means. The results for the $\mathrm{CH}$ treated with $\mathrm{CaO}$ were greater than those treated with $\mathrm{Ca}(\mathrm{OH})_{2}$, indicating that the $\mathrm{CH}$ alkaline treatment with $\mathrm{CaO}$ can be more efficient than when treated with $\mathrm{Ca}(\mathrm{OH})_{2}$.

\section{Thermal $\mathrm{Ca}(\mathrm{OH})_{2}$ contrast:}

According to Table 3, the estimated means for all the parameters behaved negatively for the samples subjected to heat when compared to the estimated averages of the parameters for the $\mathrm{CH}$ treated with $\mathrm{Ca}(\mathrm{OH})_{2}$.

\section{CaO contrast: thermal}

Estimated means between the treatment parameters compared in this contrast can be found in Table 3. The alkaline treatment may have provided most of the fiber for fermentation, with it being more effective when compared to the thermal treatment associated with nutrients being unavailable due to excessive heat during the thermal treatment.

\section{Conclusion}

Treating cocoa husks with calcium hydroxide and calcium oxide improves the gastrointestinal kinetic parameters of the cocoa husks, this is primarily as it improves the fermentation pattern of the fibrous fractions. Alkaline treatments which use calcium oxide are better than those using calcium hydroxide. Thermally treating cocoa husks is not recommended.

\section{Acknowledgements}

The authors would like to thank the Brazilian National Council for Scientific and Technological Development (INCT em Ciência Animal), the State University of Santa Cruz and the Bahia State Research Support Foundation for their financial support. 


\section{References}

ALLEN, M. S.; MERTENS, D. R. Evaluating constraints on fiber digestion by rumen microbes. Journal Nutrition, Madison, v. 118, n. 2, p. 261-270, 1987.

ALY, Z. H. Caffeine and teobromine in sheep. III Feeding of cocoa bean shell meal. Zentralbl Veterinarmed A, Hamburg, v. 28, n. 9, p. 9-711, 1981.

AREGHEORE, E. M. Chemical evaluation and digestibility of cocoa (Theobroma cacao) byproducts fed to goats. Tropical Animal Health Production, Edinburgh, v. 34, n. 4, p. 339-348, 2002.

AZEVÊDO, J. A. G.; VALADARES FILHO, S. C.; PINA, D. S.; VALADARES, R. F. D.; DETMANN, E.; PAULINO, M. F.; DINIZ, L. L.; FERNANDES, H. J. Consumo, digestibilidade total, produção de proteína microbiana e balanço de nitrogênio em dietas para ruminantes de subprodutos. Arquivo Brasileiro de Medicina Veterinária e Zootecnia, Belo Horizonte, v. 63, n. 1, p. 114-123, 2011.

CARVAlHO, G. G. P.; PIRES, A. J. V.; SILVA, F. F.;VELOSO, C. M.; SILVA, R. R.; SILVA, H. G. O.; BONOMO, P.; MENDONÇA, S. S. Comportamento ingestivo de cabras leiteiras alimentadas com farelo de cacau ou torta de dendê. Pesquisa Agropecuária Brasileira, Brasília, v. 39, n. 9, p. 919-925, 2004.

DETMANN, E.; SOUZA, M. A.; VALADARES FILHO, S. C. Métodos para análise de alimentos. Viçosa: Ed. Suprema Gráfica e Editora, 2012. 214 p.

DIJKSTRA, J.; ELLIS, J. L.; KEBREAB, E.; STRATHE, A. B.; LÓPEZ, S.; FRANCE, J.; BANNINK, A. Ruminal $\mathrm{pH}$ regulation and nutritional consequences of low $\mathrm{pH}$. Animal Feed Science and Technology, Amsterdam, v. 17, n. 1, p. 22-33, 2012.

HALL, M. B. Neutral detergent-soluble carbohydrates. Nutritional relevance and analysis. Gainesville: University of Florida, 2000. 76 p.

MACEDO, T. M.; PIRES, A. J. V.; CARVALHO, G. G. P.; LOPES, W. B.; SOARES, C. O; CHAGAS, D. M.

T. Degradabilidade da matéria seca e da fração fibrosa da cana de açúcar tratada com óxido de cálcio. Revista Brasileira de Saúde e Produção Animal, Salvador, v. 12, n. 2, p. 429-440, 2011.

MARCONDES, M. I.; VALADARES FILHO, S. C.; DETMANN, E.; VALADARES, R. F. D.; SILVA, L. F. C. E.; FONSECA, M. A. Degradação ruminal e digestibilidade intestinal da proteína bruta de alimentos para bovinos. Revista Brasileira de Zootecnia, Viçosa, MG, v. 38, n. 11, p. 2247-2257, 2009.

MAURÍCIO, R. M.; PEREIRA, L. G. R.; GONÇALVES, L. C.; RODRIGUEZ, N. M. Relação entre pressão e volume para implantação da técnica in vitro semi- automática de produção de gases na avaliação de forrageiras tropicais. Arquivo Brasileiro de Medicina Veterinária e Zootecnia, Belo Horizonte, v. 55, n. 2, p. 216-219, 2003.

OLIVEIRA, J. B.; PIRES, A. J. V.; CARVALHO, G. G. P.; RIBEIRO, L. S. O.; CRUZ, J. F.; SILVA, F. F. Subprodutos industriais na ensilagem de capimelefante para cabras leiteiras: consumo, digestibilidade de nutrientes e produção de leite. Revista Brasileira de Zootecnia, Viçosa, MG, v. 39, n. 2, p. 411-418, 2010

ØRSKOV, E. R. Trails and trails in livestock research. Abeerden: Garamond, 2002. 204 p.

PELL, A. N.; DOANE, P. H.; SCHOFIELD, P. In vitro digestibility and gas production. In: REUNIÃO ANUAL DA SOCIEDADE BRASILEIRA DE ZOOTECNIA, 34., 1997, Juiz de Fora. Anais... Juiz de Fora: SBZ, 1997. p. 109-132.

PELL, A. N.; SCHOFIELD, P.; STONE, W. C. Rates of digestion of feeds measured in vitro with computers.

In: PROCEEDINGS CORNELL NUTRITION CONFERENCE FOR FEED MANUFACTURES, 1994, Ithaca. Proceedings... Ithaca: Cornell University, 1994. n. 13-17, p. 74-81.

PINA, D. S.; VALADARES FILHO, S. C.; TEDESCHI, L. O.; BARBOSA, A. M.; AZEVÊDO, J. A.; VALADARES, R. F. D.; SOUZA, N. K. P.; FONSECA, M. A. Níveis de inclusão e tempo de exposição da canade-açúcar ao óxido de cálcio sobre parâmetros digestivos e o desempenho de novilhas Nelore. Revista Brasileira de Zootecnia, Viçosa, MG, v. 40, n. 3, p. 648-656, 2011.

PIRES, A. J. V.; CARVALHO, G. G. P.; GARCIA, R.; CARVALHO JUNIOR, J. N.; RIBEIRO, L. S. O.; CHAGAS, D. M. T. Fracionamento de carboidratos e proteínas de silagens de capim-elefante com casca de café, farelo de cacau ou farelo de mandioca. Revista Brasileira de Zootecnia, Viçosa, MG, v. 38, n. 3, p. 422427, 2009.

SANTOS, M. G. M. F; AZEVÊDO, J. A. G.; PEREIRA, L. G. R.; SILVA, T. C.; CABRAL, I. S.; FARIAS, D. S. Relação entre pressão e volume para implantação da técnica in vitro de produção de gases no trópico úmido. In: REUNIÃO ANUAL DA SOCIEDADE BRASILEIRA DE ZOOTECNIA, 47., Salvador. Anais... Salvador: SBZ, 2010. p. 1-4.

SCHOFIELD, P.; PITT, R. E.; PELL, A. N. Kinetic of fiber digestion from in vitro gas production. Journal of Animal Science, Champaign, v. 72, n. 11, p. 2980-2991, 1994.

SHIBAO, J.; BASTOS, D. H. M. Produtos da reação de Maillard em alimentos: implicações para a saúde. Revista de Nutrição, Campinas, v. 24, n. 6, p. 895-904, 2011. 